\title{
Sistem Monitoring Aliran Sungai dan Lingkungan Berbasis Smart Environment di RW 03 Kelurahan Kauman Kota Malang
}

\section{(Monitoring System for River Flow and Environment Based on Smart Environment in RW 03 Kauman Village, Malang City)}

\author{
Sutrisno ${ }^{1}$, Imam Cholissodin ${ }^{2 *}$, Arief Andy Soebroto ${ }^{3}$, Muh Arif Rahman ${ }^{4}$ \\ ${ }^{1,2,3,4}$ Fakultas Ilmu Komputer Universitas Brawijaya, JL. Veteran No.8, Malang, 65145, Indonesia
}

\begin{abstract}
ARTICLE INFO
\section{Article history}

Received : 06 April 2021

Revised : 05 Juni 2021

Accepted : 08 Juni 2021

DOI :

https://doi.org/10.33366/jast.v5i1 .2259

Keywords : CCTV; kauman malang; monitoring system; river flow; smart environment

*e-mail corresponding author : imamcs@ub.ac.id

\section{ABSTRAK}

Monitoring keadaan sungai dan lingkungan ruas jalan pada masyarakat tengah kota seringkali masih belum memadai. Di aliran sungai misalnya, masih sering dijumpai sampah yang menumpuk, sedangkan di ruas jalan masih belum dijumpai sistem keamanan yang baik. Kampung Kauman RT 03 RW III kecamatan Klojen Kota Malang merupakan salah satu kampung yang padat penduduk dan berada di pusat (titik nol) kota saat ini belum memiliki sistem keamanan ataupun satpam dan terdapat aliran sungai yang seringkali dijumpai sampah menumpuk bahkan sering menyebabkan banjir bila hujan deras. Berdasarkan kondisi lapangan di kampung Kauman dan pertemuan dengan warga yang diwakili oleh beberapa ketua RT di wilayah RW 03 Kauman yang membutuhkan pemanfaatkan integrasi teknologi smart environment dan teknologi CCTV. Hasil kegiatan pengabdian masyarakat telah dapat secara optimal dimanfaatkan untuk memenuhi kebutuhan pengawasan ataupun monitoring lingkungan tersebut. Mengingat tingkat kesibukan masyarakat perkotaan yang tinggi, dengan adanya sistem monitoring mereka dapat mengambil manfaat besar dengan dikembangkannya sistem pengawasan aliran sungai dan lingkungan yang bisa bekerja secara otomatis dan kontinyu selama 24 jam. Sistem yang dibuat telah mampu memudahkan sekaligus membantu masyarakat untuk monitoring lingkungan dan aliran sungai secara lebih efektif, efisien, dan modern.
\end{abstract}

\section{PENERBIT}

\section{UNITRI PRESS}

J1. Telagawarna, TlogomasMalang, 65144, Telp/Fax: $0341-565500$

\section{(c) (1) (2)}

This is an open access article under the Creative Commons \begin{tabular}{ll} 
Attribution-ShareAlike $\quad \mathbf{4 . 0}$ \\
\hline
\end{tabular} International License. Any further distribution of this work must maintain attribution to the author(s) and the title of the work, journal citation and DOI. CC-BY-SA

Cara Mengutip : Sutrisino, S., Cholissodin, I., Soebroto, A.A., Rahman, M.A. (2021). Sistem Monitoring Aliran Sungai dan Lingkungan Berbasis Smart Environment di RW 03 Kelurahan Kauman Kota Malang. JAST : Jurnal Aplikasi Sains dan Teknologi, 5(1), 12-20. doi:https://doi.org/10.33366/jast.v5i1.2259 


\section{PENDAHULUAN}

Letak Kelurahan Kauman dekat pusat kota mengakibatkan lingkungan menjadi ramai. Jalan-jalan kecil sering dilalui oleh beberapa orang di luar warga kelurahan Kauman untuk berbagai kepentingan. Jalan di kelurahan Kauman juga sering dijadikan sebagai jalur alternatif menuju pusat kota, sehingga menjadi fasilitas penting bagi warga kota Malang. Saat ini, kondisi jalan banyak yang rusak dan berlubang. Kerusakan jalan disebabkan karena beberapa hal, diantaranya disebabkan oleh air, iklim, lalu lintas, dan material (1). Jalan yang rusak dan berlubang dapat membahayakan bagi orang yang sedang berkendara atau bahkan sedang berjalan kaki, tentunya akan mempertinggi tingkat kecelakaan. Ketika sedang hujan dan air menggenang, kerusakan dan lubang di jalan tidak kelihatan, berakitat semakin membahayakan bagi orang yang melewatinya. Perbaikan jalan secara cepat sangat perlu dilakukan, untuk itu diperlukannya pemantau jalan yang mampu bekerja secara berkesinambungan.

Pemantau atau sering disebut dengan CCTV (Closed Circuit Television) dapat digunakan untuk memantau secara tertutup dengan menggunakan sinyal. Penggunaan CCTV dapat bermanfaat untuk mengetahui jalan yang rusak dan sekaligus dapat digunakan memantau keadaan lingkungan sekitar aliran sungai, seperti pada penelitian sebelumnya mengenai kamera CCTV dengan bendungan katulampa dapat diketahui tingkat ketinggian dari air di bendungan dengan ketepatan yang baik (2), kemudian ada juga yang menggunakan untuk monitoring lalu lintas (3) (4). Disamping itu, penggunaan CCTV dapat untuk membantu meningkatkan keamanan di kelurahan Kauman. CCTV dapat dipergunakan sebagai pelengkap sistem keamanan yang dapat dipasang sesuai kebutuhan dengan mudah (5). Misal, untuk meminimalisir terjadinya kehilangan barang, yaitu dengan menggunakan CCTV untuk memantau secara terus menerus selama 24 jam sehari. Rekaman hasil dari CCTV dapat dijadikan alat bukti persidangan apabila diminta dari pihak penyidik, kejaksaan, dan/atau instansi penegak hukum lainnya (6).

Beberapa kendala dalam implementasi CCTV pada beberapa daerah di Kota Malang, seperti terjadi di sekitar Jembatan Muharto, disinyalir ada oknum tidak bertanggung jawab yang merusaknya. Hal ini dikawatirkan dapat terjadi juga di kelurahan Kauman RW 3. Padahal dengan pemasangan CCTV, dapat memberikan dampak positif bagi warga masyarakat. Warga akan segan dan takut untuk membuang sampah di sungai dan warga dapat mengetahui kondisi jalan yang banyak dilalui orang ataupun jalan yang rusak. Dampak positif lain ialah dapat diketahuinya pelaku kejahatan yang terjadi di area sekitar tempat pemasangan CCTV.

Budidaya ikan dari warga sekitar kelurahan Kauman dulunya telah berhasil dalam meningkatkan perekonomiannya, dimana cara budidaya ikan dilakukan dengan menggunakan keramba ikan. Banyak warga di luar kelurahan Kauman ikut budidaya ikan menggunakan keramba ikan di sungai Kasin kelurahan Kauman. Meskipun air yang mengalir tidak jernih, ternyata ikan masih bisa tumbuh dengan baik (7). Menurut Jumadi, dalam postingan rri.co.id yang mengatakan bahwa sampah menjadi masalah serius untuk budidaya ikan pada aliran sungai ini. Meskipun pemerintah kota telah mengeluarkan 
peraturan daerah terkait pembuangan sampah di sungai, namun masih sering diabaikan warga masyarakat. Kesadaran masyarakat untuk tidak membuang sampah di sungai dan menciptakan kebersihan lingkungan kelurahan Kauman masih perlu ditingkatkan. Selain memberikan sosialisasi terkait kebersihan daerah aliran sungai, seharusnya pemerintah Kota Malang juga melibatkan lembaga lain seperti Satpol PP untuk memberantas para pelaku pembuangan sampah ke sungai. Hal lain yang dapat dilakukan pemerintah kota ialah melakukan lomba untuk tata kelola wilayah dalam hal kebersihan yang bersifat kontinyuitas atau berkelanjutan. Selama ini lomba hanya berlaku pada 3 bulan awal dan terabaikan untuk bulan selanjutnya. Hal ini dianggap kurang efektif karena hanya berdampak positif sementara saja.

Menurut Undang-Undang Nomor 32 Tahun 2009 tentang Perlindungan dan Pengelolaan Lingkungan Hidup pasal 98 ayat 1, pidana penjara paling singkat 3 tahun dan paling lama 10 tahun untuk pelanggar pembuang sampah (8). Sementara denda minimal 3 miliar dan maksimal 10 miliar. Selain itu, untuk Peraturan Daerah juga memberikan sangsi tersendiri untuk pelanggar berupa denda Rp 500.000,00 untuk denda minimalnya. Tetapi, agar bisa membuktikan terhadap yang membuang sampah di sungai saat ini masih mengalami kesulitan. Hal ini dikarenakan warga membuang secara diam-diam dan lebih sering dilakukan pada malam hari. Warga masih kesulitan untuk bisa memantau dalam 24 jam sehari terhadap pembuang sampah di sungai. Sementara yang bisa dilakukan hanya berjaga di sekitar sungai pada saat-saat tertentu, dan tidak dapat dilakukan secara rutin. Tindakan yang telah dilakukan masih tidak efektif karena kesulitan mengharap warga untuk dapat senantiasa melakukan pengamatan terus menerus. Dari permasalahan tersebut, maka dibutuhkan implementasi CCTV dengan berbagai kelebihannya yang dapat bekerja otomatis (9), sesuai dengan kondisi area pengamatan, kualitas gambar, jumlah gambar per detik, dan tipe perekaman (10), untuk memantau aliran sungai dan lingkungan berbasis Smart Environment di RW 03 Kelurahan Kauman Kota Malang.

\section{METODE KEGIATAN}

Metode pelaksanaan kegiatan yang akan dilakukan di lingkungan RT-03 RW-03 Kelurahan Kauman kecamatan Klojen Kota Malang. Metode pelaksanaan ini diwujudkan sehingga menjadi solusi untuk mengatasi berbagai permasalahan utama dalam mencapai tujuan.

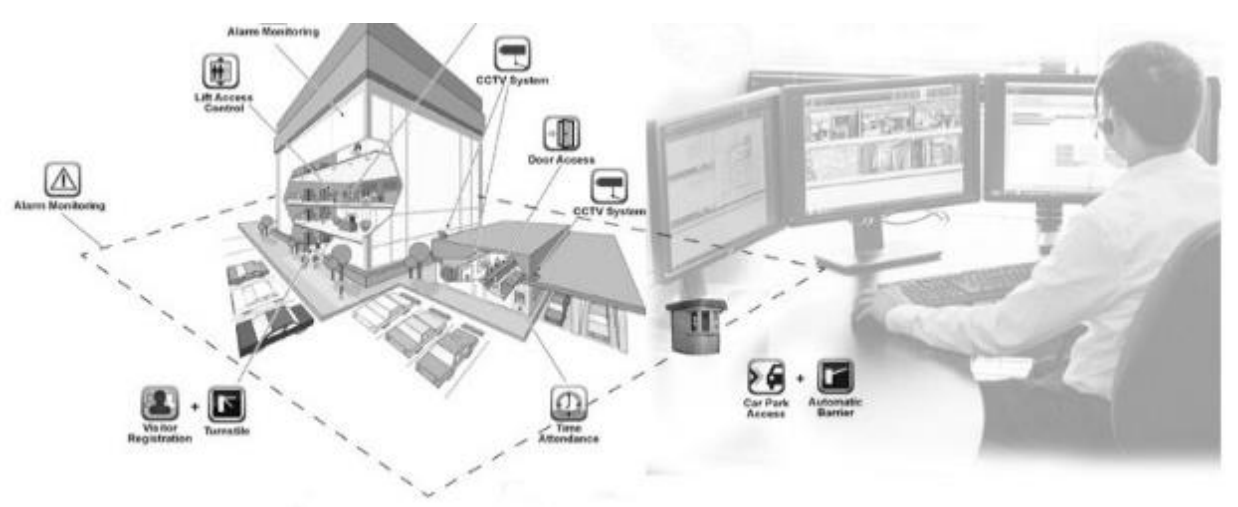

Gambar 1. Ilustrasi dari Sistem CCTV 
- Analisis dan Identifikasi Kebutuhan. Tahapan ini sebagai tahapan awal untuk melakukan identifikasi kebutuhan sistem monitoring berbasis CCTV, sehingga dapat diidentifikasi dengan baik pengawasan di lingkungan RT-03 RW-03 Kelurahan Kauman Klojen Kota Malang.

- Instalasi Sistem CCTV.

Penerapan Sistem monitoring seperti pada Gambar 1, berbasis perangkat lunak ini dilakukan sesuai dengan desain model sistem yang telah dibuat.

- Pelatihan Penggunaan Aplikasi CCTV.

Kegiatan pelatihan dan pendampingan pada hari Minggu, 20 Oktober 2019 dilakukan kepada petugas yang ditunjuk oleh ketua RT-03 RW-03 Kelurahan Kauman kecamatan Klojen Kota Malang yang akan melakukan pemantauan lingkungan, baik aliran sungai maupun ruas-ruas jalan. Selain pelatihan serta pendampingan, disisipkan pula tahap pemberian tutorial cara mengoperasikan aplikasi.

\section{KARYA UTAMA dan ULASAN KARYA}

Tabel 1. Hasil Kegiatan Pengabdian

\begin{tabular}{cll}
\hline \hline No & \multicolumn{1}{c}{ Kegiatan } & Hasil/ Dampak dan Manfaat Kegiatan \\
\hline \hline 1. & $\begin{array}{l}\text { Melakukan survey secara } \\
\text { langsung ke RT-03 RW-03 } \\
\text { Kelurahan Kauman }\end{array}$ & $\begin{array}{l}\text { Identifikasi kondisi lingkungan RT-03 } \\
\text { RW-03 Kelurahan Kauman }\end{array}$ \\
\hline 2. & $\begin{array}{l}\text { Diskusi secara interaktif dengan } \\
\text { Ketua RT-03 RW-03 Kelurahan } \\
\text { Kauman }\end{array}$ & $\begin{array}{l}\text { Menyambung relasi dan pengabdian } \\
\text { masyarakat secara professional }\end{array}$ \\
\hline 3. & $\begin{array}{l}\text { Mendata kebutuhan sistem } \\
\text { monitoring kelurahan terkait } \\
\text { dengan CCTV }\end{array}$ & $\begin{array}{l}\text { Memperjelas kebutuhan RT-03 RW-03 } \\
\text { Kelurahan Kauman mengenai sistem } \\
\text { monitoring yang akan dibangun }\end{array}$ \\
\hline 4. & $\begin{array}{l}\text { Merancang titik pemasangan } \\
\text { CCTV }\end{array}$ & $\begin{array}{l}\text { Implemantasi di lapangan untuk } \\
\text { pemasangan CCTV }\end{array}$ \\
\hline & $\begin{array}{l}\text { Memberikan training dan } \\
\text { pendampingan penggunaan } \\
\text { CCTV ke beberapa pengurus } \\
\text { yang ditunjuk sebagai } \\
\text { administrator }\end{array}$ & $\begin{array}{l}\text { Staff RT-03 RW-03 Kelurahan } \\
\text { Kauman mampu mengoperasikan } \\
\text { CCTV dengan mudah }\end{array}$ \\
\hline 6. & $\begin{array}{l}\text { Mengevaluasi hasil kinerja } \\
\text { aplikasi CCTV }\end{array}$ & $\begin{array}{l}\text { Mengetahui efisiensi dan efektifitas } \\
\text { dari penerapan aplikasi CCTV }\end{array}$ \\
\hline
\end{tabular}

Pada Tabel 1, menampung hasil dari detail kegiatan pengabdian yang dievaluasi berdasar faktor kendala serta melakukan pencarian solusi bagaimana ke depannya. Evaluasi tersebut menggunakan pendekatan secara tidak langsung, melalui dialog dua arah Ketua RT serta Ketua RW dari dan ke seluruh Warga, kemudian kami berkoordinasi dengan masing-masing Ketua RT dan RW dan sebagian Warga untuk sampel penilaian hasil kegiatan melalui musyawarah. Kemudian digunakan juga faktor efektifitas dan efisiensi sebagai ukuran hasil kegiatan pengabdian. Fokus dan luaran kegiatan ini adalah 
sebagai edukasi kepada Masyarakat terkait penggunaan dan pemanfaatan teknologi CCTV dan publikasi dalam bentuk jurnal pengabdian masyarakat.

Pada kegiatan pengabdian ini, kami melakukan pemasangan sebanyak 4 camera CCTV dari 8 slot yang ada, jadi masih tersisa 4 slot yang masih belum dipasang. Empat kamera CCTV tersebut kami ambil dari titik-titik pengawasan yang paling urgen dan utama. Titik pertama diletakkan pada pengawasan daerah aliran sungai, karena letaknya cukup jauh dengan pos keamanan sehingga membutuhkan kabel yang cukup panjang. Kemudian 3 titik lainnya dipasang tepat pada pertigaan dibawahnya pos keamanan. Berikut cara mengambil video pada waktu sebelumnya dan menyimpan hasil rekaman video pada HP/Flashdisk.

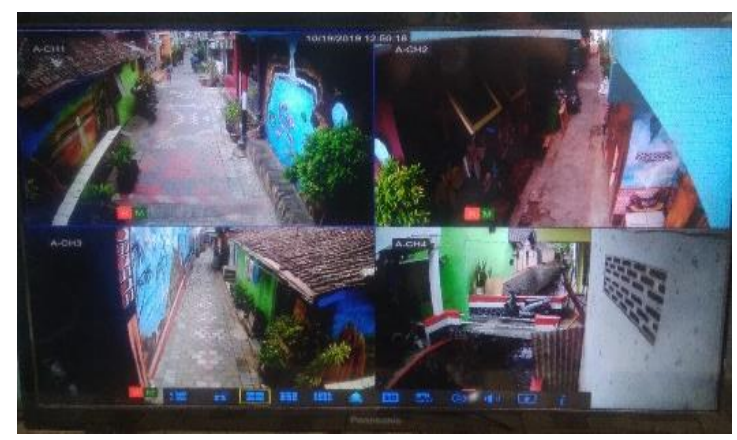

Gambar 2. Halaman CCTV 4 Channel

- Pada Gambar 2, ketika semua perangkat sudah terhubung, maka dapat dilihat melalui monitor gambar dari CCTV.

- Untuk mengambil video sesuai waktu yang ditentukan, maka pilih menu "Record Search" seperti pada Gambar 3. Pada menu tersebut, terdapat pilihan channel (kamera) yang diinginkan. Selain itu dapat dilakukan pemilihan tanggal dan jam yang ingin diambil hasil rekaman videonya. Pada CCTV ini waktu maksimal penyimpanan rekaman video yaitu satu minggu. Sehingga pengguna dapat mengambil hasil rekaman dengan waktu paling lama satu minggu sebelumnya.

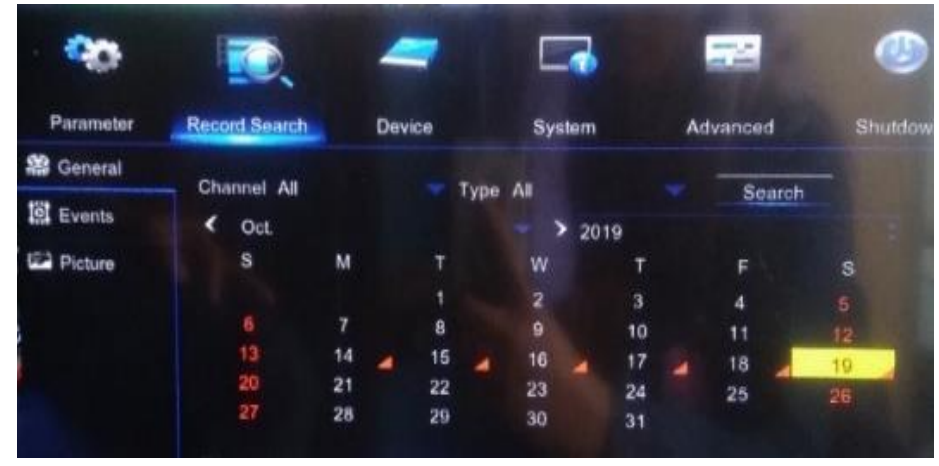

Gambar 3. Menu Record Search

- Setelah menentukan tanggal yang ingin disimpan hasil rekamannya, maka dapat dipilih waktu mulai dan waktu berakhir hasil rekaman video yang ingin dilihat. Selanjutnya klik "Play". 
- Kemudian jika ingin melakukan penyimpanan video hasil rekaman, maka dapat menekan ikon di atas warna hijau pada tipe ekstensi AVI, mp4 atau lainnya.

Berikut foto beberapa rangkaian kegiatan pengabdian masyarakat di Kauman RT 3 RW III Klojen Malang, diawali dengan diskusi informal disekitar pos keamanan dengan salah satu sesepuh Kauman (Bapak Ridwan Salman) dan ketua RT 3 dan sebagian warga, lalu dilanjutkan dengan rapat bersama ketua RT RW seperti yang ditunjukkan pada Gambar 4, yang menghasilkan beberapa usulan kegiatan yang paling utama dan menjadi kebutuhan warga.

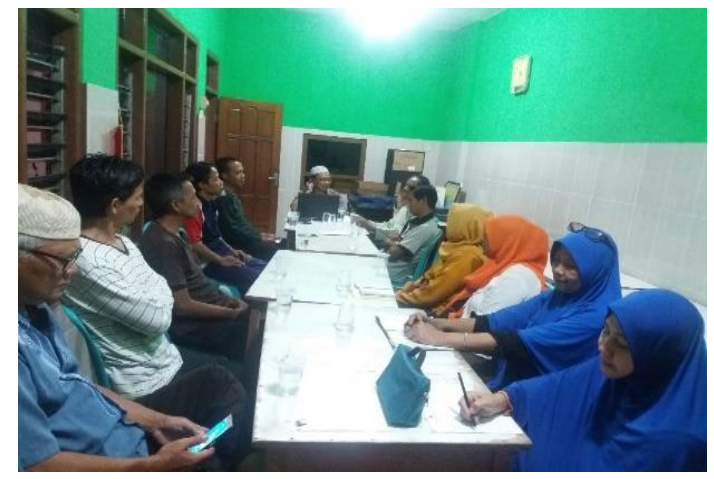

Gambar 4. Rapat di Balai RW

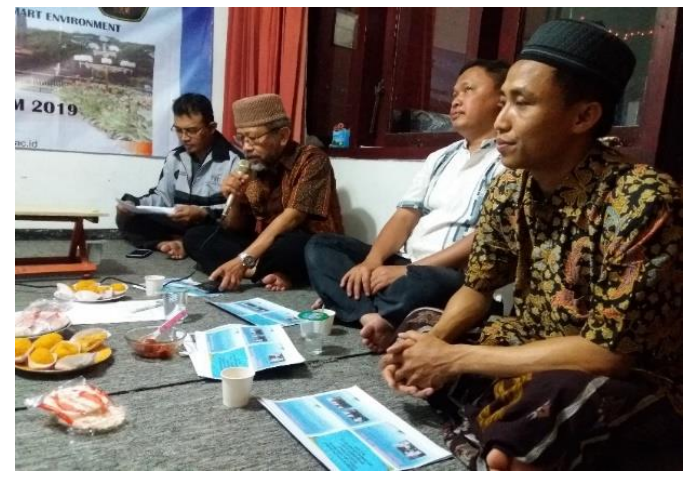

Gambar 5. Sambutan dari Ketua Pengmas

Pada Gambar 5, diberikan sambutan dari ketua kegiatan pengabdian masyarakat FILKOM UB 2019 oleh Bapak Ir. Sutrisno, M.T. Beliau menyampaikan terkait pentingnya kegiatan tersebut dan sejauh mana kegiatan tersebut telah dipersiapkan sampai pada tahap penggunaan sistem. Hal ini merupakan wujud apresiasi dan kepedulian dari kedua pihak untuk saling bekerja bersama-sama dalam membangun masyarakat yang modern, salah satunya dengan menerapkan penggunaan teknologi CCTV dengan berbagai modifikasi dan pengembangannya yang relevan sesuai keilmuan yang diteliti dari kampus sebagai inovasi dan hilirisasi beberapa hasil penelitian yang sudah dilakukan pada skala lab sebagai prototype produk untuk masyarakat. Karena dari Fakultas Ilmu Komputer (Filkom) Universitas Brawijaya (UB) sebenarnya sudah banyak sekali hasil-hasil riset yang butuh untuk segera dikemas menjadi seperti produk Industri yang siap digunakan dan diproduksi secara besar-besaran untuk berbagai elemen masyarakat dengan harga yang terjangkau.

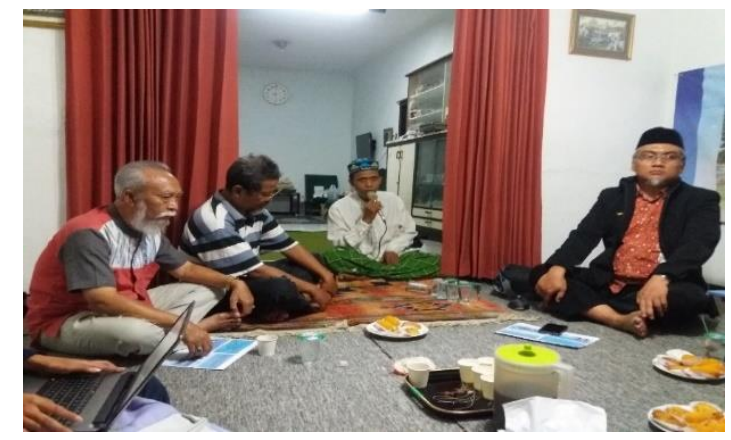

Gambar 6. Sambutan dari Ketua RT 3 RW III 


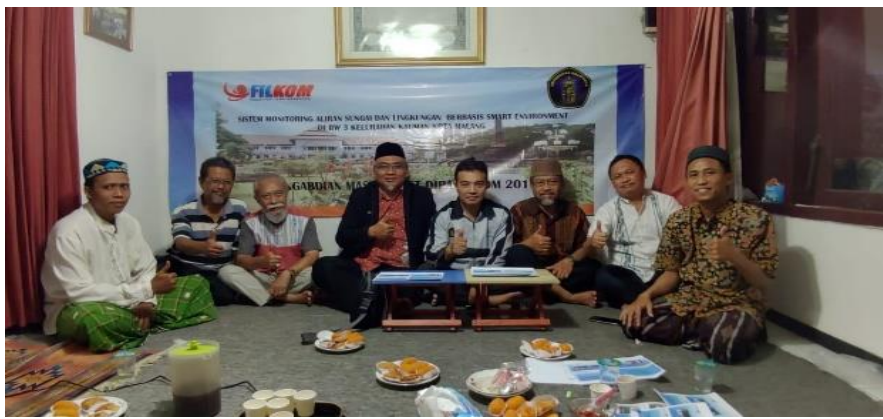

Gambar 7. Foto bersama ketika pelatihan

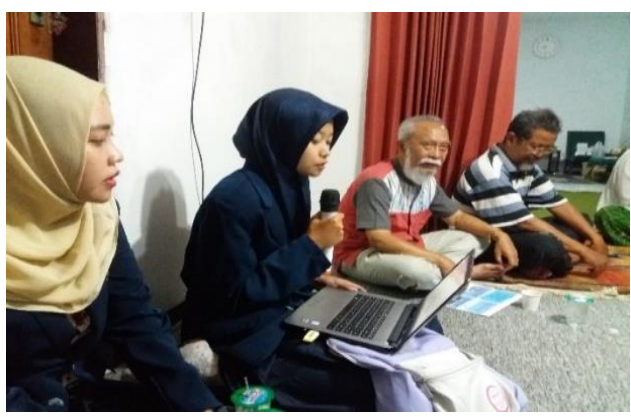

Gambar 8. Keaktifan Mahasiswa pada Kegiatan Pengabdian Masyarakat

Pada Gambar 6, diberikan sambutan dari perwakilan Ketua RT Kelurahan Kauman oleh Bapak Nurul Huda M. yang sangat bersyukur kegiatan ini dapat berjalan dengan lancar dan merasa sangat senang, dan kalau bisa kegiatan ini dapat dilakukan secara berkelanjutan setiap tahunnya, tutur beliau. Kemudian setelah itu dilakukan pelatihan penggunaan CCTV, pendampingan serta peninjauan pos keamanan sebagai tempat CCTV ditempatkan disertai diskusi dan evaluasi. Terakhir, pada Gambar 7 dan 8 kami melakukan foto bersama dan ramah tamah dengan semua yang hadir pada kegiatan pengabdian masyarakat tersebut.

\section{DAMPAK DAN MANFAAT KEGIATAN}

CCTV telah berhasil diterapkan pada kampung Kauman yang merupakan sebuah Sistem monitoring terpadu yang dapat digunakan untuk berbagai macam pengawasan. Aplikasi CCTV memeliki beberapa menu, diantaranya fitur untuk memantau kejadian pada waktu sebelumnya dalam bentuk gambar maupun video, kemudian fitur utama lainnya adalah sistem mampu untuk membackup pada media eksternal seperti flashdisk maupun harddisk sampai 7 hari ke depannya. Manfaat secara global dari sistem CCTV tersebut, yaitu dalam pengawasan keamanan dan kebersihan lingkungan, terutama pada kebersihan daerah aliran sungai. Staff RT dapat melakukan berbagai kegiatan pemantauan secara realtime.

\section{KESIMPULAN}

Hasil kegiatan pengabdian masyarakat telah dapat secara optimal dimanfaatkan untuk memenuhi kebutuhan pengawasan ataupun monitoring lingkungan tersebut. Mengingat tingkat kesibukan masyarakat perkotaan yang tinggi, dengan adanya sistem monitoring mereka dapat mengambil manfaat besar dengan dikembangkannya sistem pengawasan aliran sungai dan lingkungan yang bisa bekerja secara otomatis dan kontinyu selama 24 jam. Sistem yang dibuat telah mampu memudahkan sekaligus membantu masyarakat untuk monitoring lingkungan dan aliran sungai secara lebih efektif, efisien, dan modern. 
Diharapkan pada pengabdian masyarakat selanjutnya dapat mengembangkan akses koneksi internet sehingga monitoring kegiatan dapat dilakukan warga pada bermacammacam alat sebagai perangkat. Dan diharapkan kegiatan yang dilakukan lebih meningkatkan pengetahuan masyarakat perkampungan kota tentang kemajuan teknologi digital secara profesional dan sekaligus dapat diterapkan di RT lain-lainnya serta dapat melibatkan lebih banyak lembaga, misal bappeda, mahasiswa lintas fakultas seperti pada Gambar 8 dan juga kerjasama dengan dosen lintas fakultas untuk memperkokoh penerapan teknologi. Kemudian pembuatan standar nilai dalam bentuk indeks terkait pengukuran dari hasil pengenalan teknologi, pemberdayaan pengetahuan baru yang dapat bermanfaat untuk kesejahteraan masyarakat secara berkesinambungan. Pada kerjasama lintas fakultas, misal dengan prodi perencanaan wilayah dan kota (PWK), pengairan dan lainnya.

\section{UCAPAN TERIMAKASIH}

Penulis mengucapkan terimakasih yang sebesar-besarnya kepada Bapak Ketua RT 3 dan Bapak Ketua RW III, kemudian kepada beberapa sesepuh Kauman, serta semua Warga kampung Kauman Klojen Kota Malang yang membantu terlaksananya kegiatan pengabdian masyarakat ini.

\section{DAFTAR PUSTAKA}

[1] Y. Arta, Y. Yosritzal and R. Yuliet, "Identifikasi Masalah dan Jenis Penanganan Kerusakan Jalan Suliki - Simpang Sungai Dadok Kabupaten Lima Puluh Kota," in 4th ACE Conference, Padang, Sumatra Barat, 2017.

[2] W. A, H. M, J. L, B. Budi, I. I. Ahmad and J. A. H. Simatupang, "Pemantauan Tinggi Air Otomatis Untuk Bendungan Katulampa," Jurnal Teknik Komputer, vol. 20, no. 2, pp. 93-101, 2012.

[3] D. E. Palupi, M. A. Akbar and A. H. Brata, "Pengembangan Aplikasi Traffic Light ETilang Menggunakan Google Geofencing API Berbasis Android," Jurnal Pengembangan Teknologi Informasi dan Ilmu Komputer, vol. 2, no. 12, pp. 69826988, 2018.

[4] S. Sutrisno, I. Cholissodin, R. Christanti, C. Dewi and N. Hidayat, "Segmentasi Kendaraan Menggunakan Improve Blob Analysis (BA) Pada Video Lalu Lintas," Jurnal Teknologi Informasi dan Ilmu Komputer (JTIIK), vol. 2, no. 1, pp. 67-72, 2015.

[5] A. G. Hapsani, I. Cholissodin and A. A. Supianto, "Implementasi Metode Scale Invariant Feature Transform (SIFT) Untuk Multiple Object Tracking Pada Video CCTV," Jurnal Doro, vol. 4, no. 2, 2014.

[6] E. Marisa, H. Siswanto and R. Fathonah, "Analisis Kekuatan Hukum Closed Circuit Television (CCTV) Sebagai Alat Bukti Tidak Pidana Pencurian Dengan Pemberatan," 
Fakultas Hukum, Universitas Bandar Lampung, Bandar Lampung, 2018.

[7] H. Oktavia, "Warga Kasin Budidayakan Ikan Di Sungai Kumuh Jantung Kota Malang," Malang, 2019.

[8] P. Indonesia, Undang-Undang Nomor 32 Tahun 2009 tentang Perlindungan dan Pengelolaan Lingkungan Hidup Pasal 98 Ayat 1, Jakarta: Sekretariat Negara, 2009.

[9] A. Rohmadi, "Monitoring CCTV Digital Secara Online Melalui Internet \& Mobile Phone Pada Jaringan Wireless Lan: Studi Kasus Pada PT Tiga Sinar Mandiri," Jurnal CKI On SPOT, vol. 9, no. 1, pp. 21-28, 2016.

[10] B. B. Sitorus, "Konfigurasi DVR Berdasarkan Situasi Area Pengamatan Untuk Efisiensi Media Penyimpanan : Studi Kasus Lab Komputer," in Seminar Nasional Aplikasi Teknologi Informasi 2009 (SNATI 2009), Yogyakarta, 2009. 